\title{
Pengaruh Gaya Kognitif Terhadap Hasil Belajar Matematika Pada Mahasiswa Semester IV Jurusan PGSD UPP Denpasar Universitas Pendidikan Ganesha Tahun Ajaran 2016/2017
}

\author{
I Gusti Agung Ayu Wulandari ${ }^{1}$, Gusti Ngurah Sastra Agustika ${ }^{2}$ \\ ${ }^{12} J u r u s a n$ Pendidikan Guru Sekolah Dasar (PGSD), Universitas Pendidikan Ganesha, Singaraja, Indonesia.
}

\author{
A R T I C L E I N F O \\ Article history: \\ Received 15 Desember \\ 2017 \\ Received in revised form \\ 30 Desember 2017 \\ Accepted 12 Januari 2018 \\ Available online 20 \\ Februari 2018

\begin{tabular}{l}
\hline Kata Kunci: \\
Gaya Kognitif, dan Hasil \\
Belajar Matematika \\
Keywords: \\
Cognitive Style, Mathematic \\
Achievement
\end{tabular}

\begin{abstract}
A B S T R A K
Penelitian ini bertujuan untuk mengetahui: pengaruh gaya kognitif terhadap hasil belajar matematika. Populasi pada penelitian ini adalah seluruh mahasiswa semester IV jurusan PGSD UPP Denpasar yang berjumlah 233 orang. Sampel diambil dengan teknik Simple Random Sampling. Rancangan penelitian yang digunakan dalam penelitian ini adalah Non-equivalen Control Group Design. Data hasil belajar pendidikan matematika dikumpulkan dengan tes hasil belajar matematika dan gaya kognitif dikumpulkan den gan tes GEFT. Data yang diperoleh dianalisis dengan menggunakan ANAVA berbantuan SPSS 15.0 for windows. Hasil penelitian ini menunjukkan bahwa terdapat pengaruh gaya kognitif terhadap hasil belajar dengan nilai $\mathrm{F}=$ 22,676 dengan taraf signifikan $0,05(0,00<0,05)$
\end{abstract}

\section{A B S T R A C T}

This study aims at knowing the effect of cognitive style toward mathematic achievement. This study took 233 students in the fourth semester in PGSD department UPP Denpasar as the population. The sample of study was chosen using simple random sampling technique. This study applied Nonequivalent Control Group Design as the study design. The data of mathematic achievement and cognitive style were collected through achievement test and GEFT test. The data were then analysed by using ANAVA through SPSS 15.0 for windows. The result of the study showed that the coefficient $(F)$ of the effect of cognitive style toward mathematic achievement was about 22, 676 with the significance level of $0,05(0,00<0,05)$.

Copyright (C) Universitas Pendidikan Ganesha. All rights reserved.

\section{Pendahuluan}

Pembelajaran adalah suatu proses interaktif antara pendidik dan siswa guna mencapai tujuan pembelajaran yang diinginkan. Dalam hal ini pendidik memegang peranan yang amat penting, selain sebagai fasilitator, pembimbing, pendidik juga berperan menciptakan suasana belajar yang menyenangkan sehingga berdampak positif pada pencapaian hasil belajar.

Pendidik merupakan faktor penting dalam terciptanya proses pembelajaran, Undiksha sebagai sebuah lembaga kependidikan formal yang mencetak calon tenaga pendidik dikenal sebagai sebuah wahana untuk mencetak calon pendidik yang berkualitas. Seorang pendidik yang berkualitas hendaknya memiliki kompetensi yang memadai. Kompotensi Pendidik merupakan seperangkat pengetahuan, ketrampilan dan perilaku yang harus dimiliki, dihayati, dikuasai, dan dilaksanakan oleh Pendidik dalam melaksanakan tugas kefrofesionalan. Berdasarkan Peraturan Pemerintah (PP) Nomor 18 Tahun 2007 tentang pendidik, dinyatakan bahwasannya kompotensi yang harus dimiliki oleh Pendidik meliputi kompotensi pedagogik, kompetensi kepribadian, kompetensi sosial dan kompetensi profesional yang

\footnotetext{
1 Corresponding author.

E-mail addresses: ayu.wulandari@undiksha.ac.id (I Gusti Agung Ayu Wulandari)
} 
diperoleh melalui pendidikan profesi. Keempat kompetensi tersebut tidak berdiri sendiri melainkan saling berhubungan dan saling mempengaruhi serta saling mendasari satu sama lain.

Salah satu kompetensi tersebut adalah kompetensi profesional, kompetensi ini diantaranya berhubungan dengan kemampuan pendidik dalam penguasaan materi pelajaran sesuai dengan bidang studi yang dihajarkan. Untuk memenuhi kompetensi tersebut maka seorang calon pendidik terutama yang kuliah mengambil jurusan PGSD hendaknya memahami secara substansial materi pembelajaran di SD terutama 5 mata pelajaran wajib yaitu Bhs.Indonesia, Matematika, IPA, IPS, dan PKN. Pendidikan Matematika merupakan salah satu mata kuliah di PGSD yang tingkat kesulitannya dipandang lebih sukar apabila dibandingkan dengan mata kuliah lain. Hal ini terbukti dengan nilai yang diperoleh mahasiswa angkatan 2015 pada mata kuliah Matematika I cukup memprihatinkan. Nilai tersebut dapat dilihat pada tabel dibawah ini:

Tabel 1 Nilai Pendidikan Matematika I Mahasiswa Angkatan 2015 UPP Denpasar Undiksha

\begin{tabular}{cccccccc}
\hline \multirow{2}{*}{ No } & \multirow{2}{*}{ Kelas } & \multicolumn{7}{c}{ Nilai } & \multirow{2}{*}{ Jumlah } \\
\cline { 2 - 6 } & A & B & C & D & E & \\
\hline 1 & I & 1 & 39 & 7 & & & 47 \\
2 & J & 2 & 36 & 9 & & & 46 \\
3 & K & 1 & 39 & 6 & & & 47 \\
4 & L & 2 & 34 & 11 & & 46 \\
5 & M & 0 & 35 & 11 & & 233 \\
\hline
\end{tabular}

Dari tabel tersebut dapat diketahui bahwa dari 233 mahasiswa hanya 6 orang yang mendapat nilai A $(2,57 \%), 183$ orang mendapatkan nilai B (78,5\%), dan 44 orang mendapatkan nilai C (18,8 \%). Hasil tersebut memaparkan bahwa nilai yang diperoleh mahasiswa yang menempuh mata kuliah pendidikan matematika I tergolong rendah dan jauh dari apa yang diharapkan. Sehingga bisa dikatakan bahwa kompetensi profesional untuk memahami materi matematika SD pada mahasiswa PGSD Angkatan 2015 UPP Denpasar Undiksha belum maksimal.

Nilai yang diperoleh mahasiswa tersebut merupakan hasil dari proses belajar yang sudah mereka lakukan selama 1 semester lamanya. Hasil belajar tersebut merupakan suatu indikasi dari perubahanperubahan yang terjadi pada diri mahasiswa setelah mengalami proses pembelajaran. Dari hasil belajar inilah dapat dilihat keberhasilan mahasiswa dalam memahami suatu materi kuliah.

Salah satu karakteristik yang dimiliki oleh mahasiswa adalah gaya kognitif. Menurut Reta (2012), gaya kognitif merupakan variasi individu dalam hal memandang suatu objek, penerimaan informasi, mengingat, berpikir, berinteraksi, dan menggunakan strategi dalam melakukan tugas.

Sejalan dengan hal tersebut, Woolfolk (dalam Uno, 2010:187) membedakan gaya kognitif berdasarkan dimensi perbedaan aspek psikologis yang terdiri dari field independent dan field dependent.

\section{1) Gaya Kognitif Field Independent}

Mahasiswa yang memiliki gaya kognitif field independent (FI) cenderung untuk mengorganisasikan materi sendiri sesuai dengan kepentingannya dan cenderung untuk merumuskan sendiri tujuan belajar. Selain itu, mahasiswa yang memiliki gaya kognitif field independent (FI) juga cenderung lebih mampu menggunakan pendekatan analogi dalam menyelesaikan masalah. Biasanya mereka lebih mandiri dalam mengorganisir pengetahuan atau merestrukturisasi kognitif. Degeng (1989) menyatakan individu yang memiliki gaya kognitif field independent cenderung melakukan analisis dan sintesis terhadap informasi yang dipelajari. Individu dengan gaya kognitif field independent lebih berminat pada bidang sains, dan biasanya lebih berhasil dalam bidang-bidang lainnya (Degeng 1989).

\section{2) Gaya Kognitif Field Dependent}

Karakteristik mahasiswa yang memiliki gaya kognitif field dependent (FD) dalam pembelajaran yaitu cenderung menerima konsep dan materi secara umum, agak sulit menghubungkan konsep-konsep dalam materi dengan pengalaman sendiri atau pengetahuan awal yang telah mereka miliki, suka mencari bimbingan dan petunjuk dari pendidik, memerlukan hadiah atau penghargaan untuk memperkuat interaksi dengan pendidik, suka bekerja dengan orang lain dan menghargai pendapat dan perasaan orang lain, lebih suka bekerja sama daripada bekerja sendiri, kurang mampu dalam menganalisis, kurang mampu mengorganiskan informasi secara mandiri dan lebih menyukai organisasi materi yang disiapkan oleh pendidik. 
Mahasiswa yang memiliki gaya kognitif field dependent lebih menyukai mata pelajaran sosial dan tidak menyukai mata pelajaran matematika dan sains. Ia cenderung melepaskan diri dari bidang matematika dan ilmu alam.

Dari pernyataan para ahli di atas, dapat dirangkum bahwa gaya kognitif adalah karakteristik yang dimiliki oleh seseorang dalam hal memandang suatu objek, menerima dan memproses informasi, mengingat, berpikir, berinteraksi, dan menggunakan informasi tersebut untuk menyelesaikan suatu tugas dan memecahkan masalah dengan dimensi perbedaan aspek psikologis gaya kognitif dibedakan menjadi field independent dan field dependent.

Mengetahui gaya kognitif setiap mahasiswa sehajanya dapat membantu dosen untuk memberikan stimulus yang tepat kepada mahasiswa tersebut sesuai dengan gaya kognitif yang dimilikinya sehingga hasil tersebut mampu memaksimalkan potensi yang ada pada diri mahasiswa tersebut.

Berdasarkan uraian latar belakang tersebut, maka dilakukan penelitian yang berjudul "Pengaruh Gaya Kognitif Terhadap Hasil Belajar Pendidikan Matematika II Pada Mahasiswa Semester IV Jurusan PGSD UPP Denpasar".

\section{Metode}

Jenis penelitian yang digunakan adalah eksperimen dengan jenis quasi exsperiment. Tempat penelitian dilakukan di Jurusan PGSD UPP Denpasar Universitas Pendidikan Ganesha Singaraja. Waktu penelitian dilakasanakan pada bulan April 2017 sampai Nopember 2017. Populasi pada penelitian ini berjumlah 233 mahasiswa dengan rincian sebagai berikut:

Tabel 2 Jumlah Populasi

\begin{tabular}{ccc}
\hline No & Kelas & Jumlah \\
\hline 1 & I & 47 \\
2 & J & 47 \\
3 & K & 46 \\
4 & L & 47 \\
5 & M & 46 \\
\hline & & 233 \\
\hline
\end{tabular}

Kelas dibentuk sebagaimana mestinya tanpa ada campur tangan dari peneliti. Pengambilan sampel acak sederhana dilakukan dengan cara undian. Sampel yang diambil terdiri dari dua kelas, setiap kelas dikelompokkan lagi menjadi dua kelompok yaitu kelompok siswa yang memiliki gaya kognitif fieldindependent dan kelompok siswa yang memiliki gaya kognitif field-dependent.

Variabel terikat dalam penelitian ini adalah hasil belajar pendidikan matematika II dan variabel bebasnya adalah gaya kognitif dengan dua dimensi yaitu gaya kognitif field independent dan gaya kognitif field dependent.

Data mengenai hasil belajar matematika dikumpulkan melalui tes hasil belajar matematika sesuai dengan kisi-kisi yang disusun. Tes tersebut berbentuk pilihan ganda (objektif) yang diperluas dengan empat alternatif pilihan termasuk alasan mengapa memilih jawaban tersebut. Data mengenai gaya kognitif dikumpulkan menggunakan tes standar yaitu GEFT (Group Embedded Figure Test) yang telah dikembangkan oleh Witkin, Oltman \& Raskin 1967 dan telah diterjemahkan oleh Degeng.

Hipotesis yang diajukan berbunyi "tidak terdapat pengaruh gaya kognitif terhadap hasil belajar pendidikan matematika pada mahasiswa semester IV Jurusan PGSD UPP Denpasar Universitas Pendidikan Ganesha Tahun ajaran 2016/2017." .Secara statistik dapat dirumuskan sebagai berikut.

$$
\begin{aligned}
& H_{0}: \mu B_{1}=\mu B_{2} \\
& H_{1}: \mu B_{1} \neq \mu B_{2}
\end{aligned}
$$

Kriteria yang digunakan adalah dengan membandingkan harga Fhitung dengan Ftabel pada taraf signifikan $5 \%$ dengan db pembilang (b-1) dan db penyebut ( $\mathrm{N}$-ab).Aturan keputusan dalam perhitungan ini adalah jika Fhitung lebih besar dari pada Ftabel, maka H1 diterima dan H0 ditolak yang artinya terdapat perbedaan variabel dependen antar kelompok. 


\section{Hasil dan Pembahasan}

\section{Hasil}

Tabel 3. Ringkasan Uji Analisis ANAVA AB

\begin{tabular}{cccccc}
\hline Sumber Varians & JK & Dk & RJK & Fhitung & F tabel \\
\hline Antar Kelompok A & 1222,545 & 1 & 1222,545 & 5,401 & 3,955 \\
Antar Kelompok B & 5131,636 & 1 & 5131,636 & 22,672 & 3,955 \\
Antar Kelompok AB & 1606,545 & 1 & 1606,545 & 7,098 & 3,955 \\
Dalam Kelompok & 19012,364 & 84 & 226,338 & & \\
\hline Total & $\mathbf{2 6 9 7 3 , 0 9 1}$ & $\mathbf{8 7}$ & & & \\
\hline
\end{tabular}

Berdasarkan hasil analisis di atas, diperoleh nilai $F_{\text {hitung }}=22,672$ dan $F_{\text {tabel }}=3,955$. Ini berarti $F_{\text {hitung }}>$ $\mathrm{F}_{\text {tabel }}(22,672>3,955)$. Itu berarti pula bahwa hipotesis $\mathrm{H}_{0}$ yang menyatakan tidak terdapat pengaruh gaya kognitif terhadap hasil belajar pendidikan matematika pada mahasiswa semester IV Jurusan PGSD UPP Denpasar Universitas Pendidikan Ganesha Tahun ajaran 2016/2017, ditolak. Dengan demikian dapat ditarik kesimpulan bahwa terdapat pengaruh gaya kognitif terhadap hasil belajar pendidikan matematika pada mahasiswa semester IV Jurusan PGSD UPP Denpasar Universitas Pendidikan Ganesha Tahun ajaran 2016/2017.

\section{Pembahasan}

Berdasarkan hasil analisis hipotesis diketahui bahwa gaya kognitif berpengaruh terhadap hasil belajar matematika mahasiswa. Gaya kognitif yang terdiri dari 2 jenis yaitu field dependent dan field indenpent ini memberikan pengaruh terhadap hasil belajar matematika terutama yang memiliki gaya belajar field dependent cenderung mudah memahami materi dan memiliki kemampuan berfikir lebih baik terhadap matematika. Jadi, berdasarkan penelitian yang telah dilakukan dan diperkuat oleh pendapat ahli maka gaya kognitif field dependent memberikan pengaruh positif terhadap hasil belajar matematika mahasiswa.

\section{Simpulan dan Saran}

Terdapat pengaruh gaya kognitif terhadap hasil belajar pendidikan matematika pada mahasiswa semester IV Jurusan PGSD UPP Denpasar Universitas Pendidikan Ganesha Tahun ajaran 2016/2017.

\section{Daftar Rujukan}

Arikunto, Suharsimi. 2012. Dasar-dasar Evaluasi Pendidikan. Jakarta: Bumi Aksara.

Candiasa, I.M. 2002. Pengaruh Strategi Pembelajaran Dan Gaya Kognitif Terhadap Kemampuan Memprogram Komputer. Jurnal Teknologi Pendidikan Universitas Negeri Jakarta, Vol. 4 No. 3 Desember 2002 (ISSN 1411-2744).

Dantes. 2012. Metode Penelitian. CV. ANDI OFFSET: Yogyakarta.

Degeng. 2001. Landasan dan Wawasan Pendidikan. Malang: Lembaga Pengembangan Pendidikan (LP3) Universitas Negeri Malang.

Dimyati. 2006. Belajar dan Pembelajaran Jakarta: PT. Rineka Cipta

Jihad. 2009.Model-model Pembelajaran Inovatif Berorientasi Konstruktivistik. Jakarta: Prestasi Pustaka.

Koyan. 2012. Statistik Pendidikan Teknik Analisis Data Kuantitatif. Universitas Pendidikan Ganesha Press: Singaraja.

Slameto. 2010. Belajar dan Faktor-faktor yang Mempengaruhinya. Jakarta: Rineka Cipta.

Sugiyono. 2009. Metode Penelitian Pendidikan (Pendekatan Kuantitatif, Kualitatif, dan R\&D). Bandung: CV. Alfabeta.

Sugiyono. 2010. Metode Penelitian Kuantitatif Kualitatif \& RND. Alfabeta. Bandung Syaodih, Nana. 2005. Landasan Psikologi Proses Pendidikan. Bandung: PT Remaja Rosdakarya Bandung. Thubroni, Muhammad dan Arif Mustofa. 2011. Belajar dan Pembelajaran. Yogyakarta: Ar-RuzzMedia. Marhaeni. 2012. Pengantar Evaluasi Pendidikan. Singaraja: Universitas Pendidikan Ganesha.

Meizum, Dewi. 2011. "Gaya Kognitif Field Dependent dan Field Independent". http://www.google.ac.id.gaya belajar/gaya-kognitif-field-dependent-dan-field.html. DiunduhTanggal 25 April 2013. 
Muhsetyo, Gatot, dkk. 2008. Pembelajaran Matematika SD. Jakarta: Universitas Terbuka.

Oliver, Richard L. 2010. Satisfaction : A Behavioral Perspective on the consumer. Routledge: Taylor \& Francis Group. New York

Poerwarminta, W.J.S. 2003. Kamus Umum Bahasa Indonesia. Jakarta: Balai Pustaka.

Rahmawati, M. 2014. Analisis Tingkat Kepuasan Mahasiswa Terhadap Pelayanan Kampus. ASSETS, Volume 4 (2). Desember 2014: 225-234

Uno, B. Hamzah. 2010. Orientasi dalam Psikologi Pembelajaran. Jakarta: Bumi Aksara.

Wena. 2008. Strategi Pembelajaran Inovatif Kontemporer. Jakarta: PT Bumi Aksara. 